\title{
The Effect of Net Working Capital on Jordanian Industrial and Energy Sectors’ Net Cash Flows Employed in Operating Activities*
}

\author{
Lina Warrad \\ Applied Science University, Amman, Jordan
}

\begin{abstract}
The primary objective of the cash flow statement is to provide useful, meaningful, and relevant information about the cash receipts and cash payments of a firm during a given period of time. Decision makers can achieve extra features of the change in net assets, the firms' financial position (liquidity and solvency), and the firm's ability to adapt to changing circumstances by affecting the amount and timing of cash flows. Cash flow statements improve comparability as they are not affected by differing accounting policies used for the same type of transactions or events. This study aims to verify the effect of net working capital (NWC), as an indicator of a company's short-term liquidity or its ability to meet short-term obligations, on Jordanian industrial and energy sectors' net operating cash flows (NOCF). A simple liner regression is used to test a period of 2008-2011 in order to conclude the extent of the effect on industrial and energy sectors. The study showed that there is a significant effect of the independent variable NWC on the dependent variable NOCF among industrial and energy sectors in Jordanian market. Whereas the adjusted $R$-squared of test is 0.854 , changes in NOCF in Jordanian industrial and energy sectors have been described by NWC. Also, the study reached that the utilities and energy sector has the lowest NWC, while the mining and extraction sector has the highest. And, electrical industries sector has the lowest NOCF, while the mining and extraction sector has the highest. Moreover, the study showed that the printing and packaging sector has the lowest NWC, while the mining and extraction sector has the highest. And, glass and ceramic industries sector has the lowest NOCF, while the utilities and energy sector has the highest.
\end{abstract}

Keywords: net working capital (NWC), net operating cash flows (NOCF), Amman Stock Exchange (ASE)

\section{Introduction}

Working capital is sometimes used to express just current assets, while net working capital (NWC) is known to be the difference between current assets and current liabilities. In investment analysis, increases in working capital are showed as cash outflows. ${ }^{1}$

The main purpose of the statement of cash flows is to provide detailed information about a firm's cash inflows and cash outflows.

\footnotetext{
* Acknowledgement: The author is grateful to the Applied Science Private University, Amman, Jordan, for the financial support granted to this research project (Grant No. DRGS-2014-2015-121).

Lina Warrad, associate professor, Faculty of Economic and Administrative Science, Accounting Department, Applied Science University. Email: __warrad@asu.edu.jo.

${ }^{1}$ Retrieved from http://people.stern.nyu.edu.
} 
The secondary purpose is to provide information concerning the firm's financing and investing activities. The statement itself is divided into three parts: operating activities, investing activities, and financing activities.

The changes in working capital are reflected in a firm's cash flow statement. Specifically, the operating cash flow part of the cash flow statement details changes in its shorter-term working capital needs. A positive working capital amount means a cash inflow for the period measured. On the other hand, a negative working capital figure means that the firm has spent more cash out than it used in managing its working capital during the year. Analyzing changes in working capital is important for firms with systematic or unsystematic cash flow needs. ${ }^{2}$

The increase in working capital means that more cash is invested in working capital and thus reduces cash flows. The effects of working capital changes are reflected in a firm's cash flow statement. By this relationship between working capital and cash flows, firms which are more efficient in managing working capital will have a higher value than similar firms with higher working capital requirements.

In order to achieve the usefulness of economic and social expansion, the Jordanian government has concentrated on developing the industrial sector; it provides the majority with new jobs and produces much of the creativity and innovation that push economic development.

Jordan is very attractive for foreign investments due to many reasons, such as safety, political stability, and its central location in the Middle East. Because of that, this paper will try to investigate the previous relations mentioned above by studying the effect of net working capital (NWC) on Jordanian industrial and energy sectors' net cash flows employed in operating activities. ${ }^{3}$

\section{Previous Studies}

The working capital performance was represented by Kaur and Singh's (2013) study which consisted of 164 manufacturing BSE 200 companies classified into 19 industries during the period of 2000-2010 based on working capital expressed by cash conversion efficiency, days operating cycle, and days working capital. The study investigated the relationship between the working capital score and profitability measured by return on assets (ROA) and return on total assets. The results of the study supported that an efficient management of working capital significantly affects profitability.

The relationship among working capital, operating cash flow, and operating income in the companies listed on the Tehran Stock Exchange was investigated by Valipour, Shooshtarian, and Ostovari’s (2012) study which applied a panel analysis to a sample of 52 companies during the period from 2000 to 2009. The results indicated that there is a positive relationship between working capital and operating profit. But there is no meaningful relationship between operating cash flows and working capital.

The evaluation of the working capital management of multinational firms was investigated by Ray's (2012) study which examined the international cash management operations, approach of performing international sales, and practice for performing foreign exchange activities. The study found that companies had changed their concerns towards low cost and efficient methods related to international working capital management decisions.

The evaluation of the relationship between working capital management and corporate performance was investigated by Mousavi and Jari's (2012) study which used indicators such as ROA, return on equity (ROE), and ratio of market value to book value for evaluating corporate performance and net liquidity balance as a

\footnotetext{
${ }^{2}$ Retrieved from http://www.investopedia.com/.

3 Retrieved from http://www.mit.gov.jo.
} 
matrix for evaluating working capital management. The researchers tested 56 financial statements in Tehran Stock Exchange. One regression model and correlation method was applied. Results showed a positive relationship between working capital management and corporate performance.

The effect of company characteristics on the working capital management was applied by Rimo and Panbunyuen's (2010) study. A quantitative method was used to examine the relationship between company characteristics and working capital management expressed by cash conversion cycle in Swedish listed companies. The company characteristics include profitability, operating cash flow, company size, sales growth, current ratio, and debt ratio. The study was applied on 40 firms in the large investment segment listed on National Association of Securities Dealers Automated Quotation (NASDAQ) OMX Stockholm Exchange, including financial data from annual reports of years of 2007-2008 in order to calculate financial ratios used in the study. The study used regression analysis and showed that profitability, operating cash flow, company size, and sales growth affect the company's working capital management. A significant positive association between profitability and the cash conversion cycle was approved. Also, a significant negative relationship was found between cash conversion cycle and operating cash flow, company size, and sales growth. Further, the study examined the industry effect and found significant positive relations with the cash conversion cycle in four industry classifications as follows: materials, industrials, health care, and information technology.

The relationship between managing operating cash flows and the cost of debt was investigated by Geile's (2007) study which indicated a positive relationship between managed operating cash flows and the cost of debt when firms use cash flow management to meet the zero operating cash flow benchmark. The study also found a more positive relation among managed operating cash flows for a group of afflicted firms.

Managing reported operating cash flow was studied by Frankel's (2005) paper. The researcher found a significant drop in non-cash working capital in the fourth quarter, which subsequently reversed in the first quarter of the next fiscal year. This temporary decrease in the fourth quarter remained significant after controlling for seasonal variation in the firm's activity level as indexed by quarterly revenues and net profit. Also, he found that firms mentioning working-capital-related compensation targets have larger fourth quarter working capital declines, but these declines are not more likely to reverse.

Moyer, Mcguigan, and Kretlow (2003) reached that working capital consists of a large portion of a firm's total investment in assets, $40 \%$ in manufacturing and 50\%-60\% in retailing and wholesale industries, respectively. The firms could decrease its financing cost and increase the funds available for development if they minimize the funds used in current assets. They found that cash helps to keep the firm liquid. It helps the firm to pay its obligations and also protects the firm from bankruptcy.

The impact of inflation on the capital budgeting process was explored by the study of Mills (1996) which showed that the cost of capital will increase rationally at the same rate as the rate of inflation on an ex ante basis.

Also, the paper mentioned that the capital budgeting process is not neutral with respect to inflation, even if output prices rise at the same rate as costs.

Use of cash flow information was presented by Kochanek and Norgaard (1988) who applied a five-year analysis of the Charter Company, which filed for voluntary bankruptcy in April 1984.

Charter's cash from operations declined to a use of $\$ 90$ million in 1983. To inspect causes in which this significant decrease could have been anticipated, operating cash flows for the Charter Company and for a sample of competing oil companies for the period of 1979-1983 were computed and compared. Instead of 
focusing on the total amount of operating cash flows, an examination was made of changes in working capital as a means of assessing the ability of the sample companies to change the timing of their operating cash flows. The analysis showed that the ability to alter the timing of cash flows, by managing operating effects in cash provided by operations, was more constrained for use in assessing a company's financial flexibility.

\section{Hypothesis}

For studying the effect of NWC on net operating cash flow (NOCF), the researcher tests the following hypothesis:

H1: There is no significant effect of the independent variable NWC on the dependent variable Jordanian industrial and energy sectors' NOCF.

\section{Research Methodology}

This section presents the research methodology adopted in this study. It explains sample selection criteria, variables of the study, research model, and hypothesis.

\section{The Research Sample}

The study examines financial reports for 12 Jordanian industrial and energetic sectors listed on the Amman Stock Exchange (ASE) for the period from 2008 to 2011.

\section{Dependent Variable of the Study}

NOCF. This is surely the key part of the cash flow statement, because it shows whether and to what extent companies can introduce cash from their operations. It is these operating cash flows which must, in the end, pay for all cash outflows due to other activities (Association of Chartered Certified Accountants [ACCA], 2007-2008).

NOCF involves the cash effect of activities that enter into the determination of net income, such as cash receipts from sales of goods and services and cash payments to creditors and employees for acquisition of inventory and expenses. The amount of cash flows increasing from operating activities is a main indicator of the extent to which the operations of the entity have generated sufficient cash flows to repay loans, maintain the operating capability of the entity, pay dividends, and make new investments without resource to external source of financing (Kieso, Weygandt, \& Warfield, 2011).

\section{Independent Variable of the Study}

NWC. The formula ${ }^{4}$ for NWC, sometimes simply referred to as working capital, is used to determine the availability of a company's liquid assets by deducting its current liabilities (Becker Conviser CPA Review, 2001):

\section{Net Working Capital $=$ Current Assets - Current Liabilities}

\section{Research Model}

In order to test the study hypothesis, the research model can be designed as follows:

$$
N O C F=-6,144,947.449+0.655 N W C+e
$$

\footnotetext{
${ }^{4}$ Retrieved from http://www.financeformulas.net/.
} 
Liner regressions. To test the research hypothesis, Statistical Package for Social Sciences (SPSS) program was used to prepare the table of analysis of variance (ANOVA).

Table 1

Model Summary

\begin{tabular}{llll}
\hline Variable & $R$ & $R$-square & Adjusted $R$-squared \\
\hline NWC & 0.926 & 0.857 & 0.854 \\
\hline
\end{tabular}

By reviewing Table 1, the researcher found that it explains the effect of the percentage of variation in the independent variable NWC explained by regression line out of the total variation on the dependent variable NOCF. Whereas the adjusted $R$-squared of test is 0.854 , changes in NOCF have been described by NWC.

Table 2

ANOVA $^{\mathrm{a}}$

\begin{tabular}{llrlll}
\hline Model & Sum of squares & df & Mean square & $F$ & Sigs \\
\hline Regression & $6.654 \mathrm{E} 17$ & 1 & $6.654 \mathrm{E} 17$ & 275.376 & $0.000^{\mathrm{b}}$ \\
Residual & $1.112 \mathrm{E} 17$ & 46 & $2.416 \mathrm{E} 17$ & & \\
Total & $7.766 \mathrm{E} 17$ & 47 & & & \\
\hline
\end{tabular}

Notes. ${ }^{a}$ : Dependent variable: NOCF. ${ }^{b}$ : Predictors: (constant), NWC.

By reviewing Table 2, the researcher found that the $P$-value $=0.000<5 \%$ is significant, and this supports the rejection of the main null hypothesis. There is no significant effect of the independent variable NWC on the dependent variable NOCF. The alternative hypothesis is also accepted, namely, there is a significant effect of the independent variable NWC on the dependent variable NOCF. Whereas the adjusted $R$-squared of test is 0.854 , changes in NOCF have been described by NWC.

\section{Statistical Analysis}

This section presents the results of the descriptive statistics for the study variables.

Table 3

The Rank of the Mean for the NWC and the NOCF

\begin{tabular}{lcccc}
\hline Sector name & Independent variable: NWC & Rank & Dependent variable: NOCF & Rank \\
\hline Chemicals & $27,292,043.5$ & 8 & $553,097.5$ & 3 \\
Glass and ceramic industries & $4,583,743.25$ & 4 & $-112,931.75$ & 2 \\
Paper and cardboard industries & $646,922.25$ & 2 & $1,585,931.25$ & 5 \\
Pharmaceutical and medical industries & $63,796,527.75$ & 11 & $1,370,967.5$ & 4 \\
Tobacco and cigarettes & $19,610,730.5$ & 7 & $22,041,448$ & 11 \\
Engineering and construction & $19,513,975.25$ & 6 & $9,600,790$ & 9 \\
Printing and packaging sector & $4,541,174.25$ & 3 & $1,832,252.25$ & 6 \\
Electrical industries sector & $27,538,677.25$ & 9 & $-3,499,610$ & 1 \\
Food and beverages & $31,737,636$ & 10 & $9,762,213.75$ & 10 \\
Mining and extraction & $653,673,372$ & 12 & $420,736,465.8$ & 12 \\
Textiles, leathers, and clothing sector & $15,145,166$ & 5 & $6,693,661$ & 8 \\
Utilities and energy sector & $-33,601,872.5$ & 1 & $2,613,491.5$ & 7 \\
\hline
\end{tabular}

By reviewing Table 3, the researcher noticed that the utilities and energy sector has the lowest NWC, while the mining and extraction sector has the highest. In addition, electrical industries sector has the lowest NOCF, while the mining and extraction sector has the highest. 
Table 4

The Rank of the Standard Deviation for the NWC and the NOCF

\begin{tabular}{lcccc}
\hline Sector name & Independent variable: NWC & Rank & Dependent variable: NOCF & Rank \\
\hline Chemicals & $6,648,503.605$ & 6 & $6,994,036.264$ & 7 \\
Glass and ceramic industries & $1,732,140.486$ & 2 & $273,236.1367$ & 1 \\
Paper and cardboard industries & $4,780,395.969$ & 4 & $611,125.6987$ & 2 \\
Pharmaceutical and medical industries & $9,037,358.355$ & 7 & $4,674,898.383$ & 5 \\
Tobacco and cigarettes & $11,693,618.09$ & 9 & $10,081,213.24$ & 9 \\
Engineering and construction & $6,493,710.616$ & 5 & $5,767,328.583$ & 6 \\
Printing and packaging sector & $328,627.2727$ & 1 & $763,939.7999$ & 3 \\
Electrical industries sector & $12,182,402.13$ & 10 & $21,469,844.77$ & 10 \\
Food and beverages & $4,569,727.871$ & 3 & $7,934,381.101$ & 8 \\
Mining and extraction & $101,661,962.8$ & 12 & $112,963,904.8$ & 11 \\
Textiles, leathers, and clothing sector & $9,876,036.067$ & 8 & $2,007,457.74$ & 4 \\
Utilities and energy sector & $37,819,054.73$ & 11 & $182,266,496.9$ & 12 \\
\hline
\end{tabular}

By reviewing Table 4, the researcher noticed that the printing and packaging sector has the lowest NWC, while the mining and extraction sector has the highest. In addition, glass and ceramic industries sector has the lowest NOCF, while the utilities and energy sector has the highest.

Figure 1 indicates the effect of the independent variable NWC on the dependent variable NOCF at the highest NWC and NOCF. The x-axis (horizontal line) indicates the independent variable NWC and the y-axis (vertical line) indicates the dependent variable NOCF.

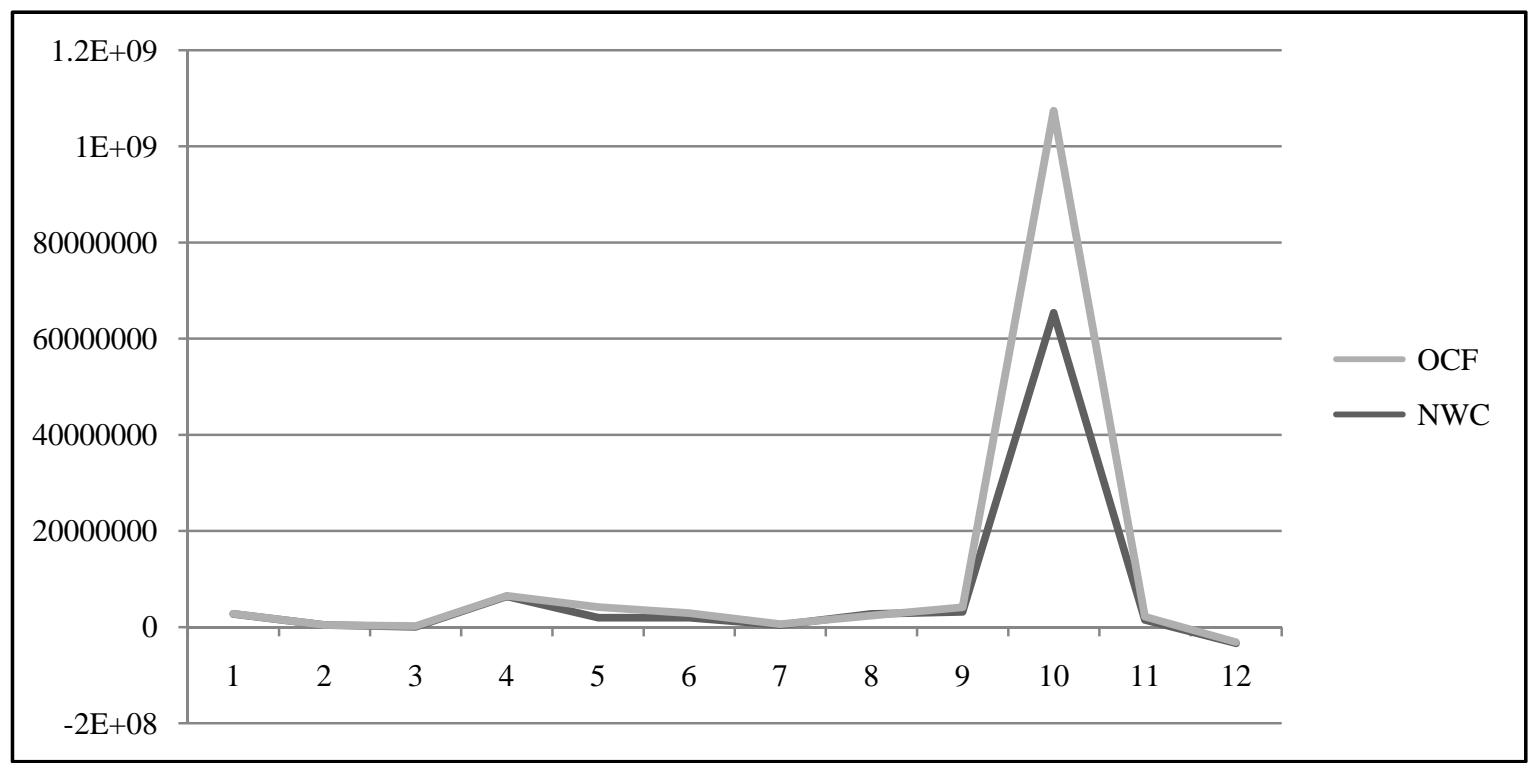

Figure 1. The effect of the independent variable NWC on the dependent variable NOCF at the highest NWC and NOCF.

\section{Summary and Conclusion}

This study is done to approve if there is a significant effect of NWC on Jordanian industrial and energy sectors' NOCF used in operating activities. The results found that Jordanian industrial and energy sectors' NOCF is significantly affected by these sectors’ NWC. 
A negative coefficient for constant in a previous linear regression is related to the dependent variable, and a negative value for the study intercept should not be a cause for attention. This simply means that the expected value on the dependent variable will be less than zero, when all independent variables are set to zero. Note that for some dependent variables, this would be expected. For instance, if the mean value of dependent variable is negative, it would not be unexpected that the constant is negative; if the study got a positive value for the constant in this case, it might be a reason for concern relating to independent variables. ${ }^{5}$

The study results approved the results of some previous studies, such as Kochanek and Norgaard (1988) which showed that the ability to alter the timing of cash flows, by managing operating effects in cash provided by operations, was more constrained for use in assessing a company's financial flexibility.

Also, Moyer et al. (2003) found that working capital consists of a large portion of a firm’s total investment in assets, performing a main part of operating cash flow activities.

On the other hand, the study differs from some previous studies such as Valipour et al. (2012) which showed that there is no meaningful relationship between operating cash flows and working capital.

The researcher will develop the result of the paper in other Jordanian sector-wise comparing studies, in order to investigate if the importance of other sectors in the total local output may make differences in the results.

\section{References}

Association of Chartered Certified Accountants [ACCA]. (2007-2008). Paper F7, financial reporting (International). For Exams in December 2007 and June 2008.

Becker Conviser CPA Review. (2001). Part 2: Financial reporting.

Frankel, R. (2005). Managing reported operating cash flow: An empirical investigation of fourth quarter working capital decreases and benchmark beating (Sloan School of Management, Massachusetts Institute of Technology).

Geile, A. L. (2007). Cash flow management and the cost of debt (A dissertation submitted to the Faculty of the Committee on Business Administration, in partial fulfillment of the requirements for the degree of Doctor of Philosophy with a major in Management in the Graduate College, the University of Arizona).

Kaur, H. V., \& Singh, S. (2013). Managing efficiency and profitability through working capital: An empirical analysis of BSE 200 companies. Asian Journal of Business Management, 5(2), 197-207.

Kieso, D. E., Weygandt, J. J., \& Warfield, T. D. (2011). Intermediate accounting: IFRS edition (Vol. 2). Hoboken, NJ: John Wiley \& Sons.

Kochanek, R., \& Norgaard, C. (1988). Analyzing the components of operating cash flow: The charter company. Accounting Horizons, 58-66.

Mills, G. T. (1996). The impact of inflation on capital budgeting and working capital. Journal of Financial and Strategic Decisions, 9(1), 79-87.

Mousavi, Z., \& Jari, A. (2012). The relationship between working capital management and firm performance: Evidence from Iran. International Journal of Humanities and Social Science, 2(2), 141-146.

Moyer, C. R., Mcguigan, J. R., \& Kretlow, W. J. (2003). Contemporary financial management (9th ed.). USA: Thomson Press.

Ray, S. (2012). Managing international working capital flow: An evaluation. Journal of Science, 1(1), 13-20.

Rimo, A., \& Panbunyuen, P. (2010). The effect of company characteristics on working capital management: A quantitative study of Swedish listed companies (Master thesis, Umeå School of Business).

Valipour, H., Shooshtarian, Z., \& Ostovari, E. (2012). Relationship between working capital, operating cash flows, and operating income: Empirical evidences from listed firms in Tehran Stock Exchange. Asian Economic and Financial Review, 2(1), 20-29.

\footnotetext{
${ }^{5}$ Retrieved from http://www.researchgate.net/.
} 